https://doi.org/10.17816/MAJ191S1119-120

\title{
DELAYED COGNITIVE DEFICIT AS A RESULT OF NEONATAL LIPOPOLYSACCHARIDE EXPOSURE: \\ A PRESUMABLE IMPLICATION OF LONG-LASTING CHANGES OF NEUROPLASTIC GENE EXPRESSION
}

\author{
A.N. Trofimov ${ }^{1}$, O.E. Zubareva ${ }^{1,2}$, A.P.Schwarz ${ }^{3}$, E.A. Veniaminova ${ }^{1,4}$, \\ K. Fomalont ${ }^{1}$, V.M. Klimenko ${ }^{1}$ \\ ${ }^{1}$ Laboratory of Neurobiology of the Brain Integrative Functions, I.P. Pavlov Department of Physiology, \\ Institute of Experimental Medicine, Saint Petersburg, Russia; \\ ${ }^{2}$ Laboratory of Molecular Mechanisms of Neuronal Interactions, I.M. Sechenov Institute of Evolutionary \\ Physiology and Biochemistry, Russian Academy of Sciences, Saint Petersburg, Russia; \\ ${ }^{3}$ Multidisciplinary Laboratory of Neurobiology, I.M. Sechenov Institute of Evolutionary Physiology \\ and Biochemistry, Russian Academy of Sciences, Saint Petersburg, Russia; \\ ${ }^{4}$ Laboratory of Psychiatric Neurobiology, Institute of Molecular Medicine, \\ Sechenov First Moscow State Medical University, Moscow, Russia

\section{ОТДАЛЕННЫЕ КОГНИТИВНЫЕ НАРУШЕНИЯ В РЕЗУЛЬТАТЕ НЕОНАТАЛЬНОГО ДЕЙСТВИЯ ЛИПОПОЛИСАХАРИДА: РОЛЬ ДОЛГОВРЕМЕННЫХ} \\ ИЗМЕНЕНИЙ ЭКСПРЕССИИ ГЕНОВ НЕЙРОПЛАСТИЧНОСТИ
}

\author{
А.Н. Трофимов ${ }^{1}$, О.Е. Зубарева ${ }^{1,2}$, А.П. Швари ${ }^{3}$, Е.А. Вениаминова ${ }^{1,4}$, \\ К. Фомалонт ${ }^{1}$, В.М. Клименко ${ }^{1}$ \\ ${ }^{1}$ Лаборатория нейробиологии интегративных функций мозга, Физиологический отдел им. И.П. Павлова, \\ ФГБНУ «Институт экспериментальной медицины», Санкт-Петербург; \\ ${ }^{2}$ Лаборатория молекулярных механизмов нейронных взаимодействий, ФГБУН «Институт эволюционной \\ физиологии и биохимии им. И.М. Сеченова РАН», Санкт-Петербург; \\ ${ }^{3}$ Междисциплинарная лаборатория нейробиологии, ФГБУН «Институт эволюционной физиологии \\ и биохимии им. И.М. Сеченова РАН», Санкт-Петербург; \\ ${ }^{4}$ Лаборатория психиатрической нейробиологии, Институт молекулярной медицины, \\ ФГАОУ ВО «Первый МГМУ им. И.М. Сеченова» Минздрава России, Москва
}

Disorders of the CNS development at an early age caused by various types of perinatal pathology, such as infectious diseases, trauma, hypoxia and ischemia, often lead to the development of cognitive brain dysfunctions in adulthood. Proinflammatory cytokines play key role in these pathological processes and can affect the expression of genes involved in the regulation of neuroplasticity. This article describes the changes in the expression of fibroblast growth factor-2 $(F g f 2)$, as well as genes encoding matrix metalloproteinase-9 (MMP-9) and tissue inhibitor of matrix metalloproteinases-1 (TIMP-1), proteins that by intercellular matrix re-modeling are involved in the regulation of neuroplasticity.

Keywords: neonatal pathology; brain development; cognitive deficit; lipopolysaccharide; neuroplasticity.

Нарушения развития ЦНС в раннем возрасте, вызываемые различными видами перинатальной патологии, такими как инфекционные заболевания, травмы, гипоксия и ишемия, часто ведут к развитию когнитивных дисфункций мозга в зрелом возрасте. Провоспалительные цитокины играют ключевую роль в развитии таких патологических процессов и могут влиять на экспрессию генов, вовлеченных в регуляцию процессов нейропластичности. В данной статье описаны изменения экспрессии генов фактора роста фибробластов-2 (FGF2), а также генов, кодирующих белки MМР-9 (матриксная металлопротеиназа 9) и ТIMР-1 (тканевой ингибитор матриксных металлопротеиназ 1), которые, регулируя состав, структуру и функционирование межклеточного матрикса, вовлечены в процессы регуляции нейропластичности.

Ключевые слова: неонатальная патология; развитие мозга; когнитивный дефицит; липополисахарид; нейропластичность.

Perinatal pathology is a well described detrimental factor for the development of CNS functioning that is involved in the etiology of chronic cognitive deficit [1]. These pathological conditions are associated with increased production of proinflammatory cytokines by the cells of the immune and nervous systems. Administrations of lipopolysaccharide (LPS) during early periods of ontogeny 
is one of most widely used and comprehensively studied models of the cognitive and behavioural effects of early-life systemic inflammation [2, 3]. Low-dose postnatal LPS treatment is known to increase cytokine production, inhibit hippocampal long-term potentiation and impair various forms of memory and learning in adulthood [4, 5]. Yet, particular molecular mechanisms of the action of pro-inflammatory factors on the cells of CNS need more investigation to be fully elucidated.

One of possible mechanisms of long-term cognitive impairments evoked by early-life inflammation is an altered production of proteins that are involved in the regulation of brain neuroplasticity. In our previous studies on Wistar rats that were treated with moderately pyrogenic doses of LPS during the $3^{\text {rd }}$ week of postnatal development, we focused on the prefrontal and hippocampal gene expression of fibroblast growth factor-2 $(F g f 2)$ as well as matrix metalloproteinase-9 (Mmp9) and tissue inhibitor of metalloproteinases-1 (Timp 1). As these particular genes are known to be implicated in both the development of CNS and memory formation, as well as their expression was described to be affected by inflammation-related events, we hypoth- esized these genes to react on the LPS treatment and serve as molecular mechanisms for abnormal brain maturation. We have found the LPS-treated animals to show decreased exploratory activity and increased static movement, impaired active avoidance learning and spatial memory formation compared to the control animals that were injected with saline [6, 7]. Impaired behavior was associated with decreased $F g f 2$ expression in the medial prefrontal cortex in comparison with vehicle-treated control. Adolescent and adult LPS-treated animals demonstrated increased anxiety-like behavior and decreased exploratory behavior in the open field arena. Gene expression of Mmp9 and Timp 1 was differentially altered in the cortex and hippocampus of pups vs. adult untrained rats and remained unchanged in rats trained in either learning task, revealing that prolonged pro-inflammatory challenge during early postnatal development negatively affects the plasticity factors involved in memory acquisition in adulthood. These results suggest that an increase in cognitive stimulation might be an effective approach to reduce the negative effects of neonatal immune challenges on brain functioning. Supported by RFBR 17-04-02116.

\section{References}

1. Zubareva OE, Klimenko VM. Increases in Proinflammatory Cytokine Levels at Early Ages as a Risk Factor for the Development of Nervous and Mental Pathology. Neuroscience and Behavioral Physiology. 2013;43(4):535-541.

2. Williamson LL, Sholar PW, Mistry RS, et al. Microglia and memory: modulation by early-life infection. The Journal of neuroscience: the official journal of the Society for Neuroscience. 2011;31(43):15511-21.

3. Zavitsanou K, Dalton VS, Walker AK, et al. Neonatal lipopolysaccharide treatment has long-term effects on monoaminergic and cannabinoid receptors in the rat. Synapse. 2013;67(6):290-299.

4. Vereker E, Campbell V, Roche E, et al. Lipopolysaccharide inhibits long term potentiation in the rat dentate gyrus by activating caspase-1. The Journal of biological chemistry. 2000;275(34):26252-8.

5. Tishkina A, Stepanichev M, Kudryashova I, et al. Neonatal proinflammatory challenge in male Wistar rats: Effects on behavior, synaptic plasticity, and adrenocortical stress response. Behavioural brain research. 2016;304:1-10.

6. Trofimov A, Strekalova T, Mortimer N, et al. Postnatal LPS Challenge Impacts Escape Learning and Expression of Plasticity Factors Mmp9 and Timp1 in Rats: Effects of Repeated Training. Neurotoxicity research. 2017;32(2):175-186.

7. Veniaminova EA, Zubareva OE. The changes in exploratory behavior and $F g f 2$ gene expression in cells of the rat brain after the early postnatal administration of bacterial lipopolysaccharide. Neurochemical Journal. 2015;9(2):127-132. 